\title{
Minuman Kesehatan Produk Fermentasi Non Susu Untuk Meningkatkan Imun Dimasa Pandemi Bagi Guru SMAN 15 Kota Semarang
}

\author{
Adi Sampurno ${ }^{1 *}$, Antonia Nani Cahyanti ${ }^{2}$, Devy Angga Gunantar ${ }^{3}$ \\ 1, 2,3, Fakultas Teknologi Pertanian, Universitas Semarang \\ 1'masdick120@gmail.com, ${ }^{2}$ nanicahyanti@gmail.com, ${ }^{3}$ angga.gunantar@gmail.com
}

\begin{abstract}
Abstrak
Produk pangan fungsional merupakan pangan yang dikonsumsi sebagai diet biasa, namun memiliki efek fisiologis dan dapat menjaga kesehatan tubuh; salah satunya adalah minuman probiotik. Berbagai macam minuman probiotik yang dikenal secara luas diproduksi dari susu sapi, sehingga harganya relatif mahal. Padahal ada beberapa produk minuman probiotik non susu seperti: kombucha/jamur dipo, water kefir, yoghurt dari sari buah dan dari sari kurma, cider/cuka apel. Pada masa pandemi Covid-19 saat ini, selain kita dituntut untuk mematuhi dan melaksanakan protokol kesehatan, juga dituntut untuk selalu menjaga kondisi kebugaran dan kesehatan tubuh dengan cara mengkonsumsi makanan yang bergizi, serta mengkonsumsi produk pangan yang dapat memelihara dan meningkatkan imunitas tubuh. Staf pendidik di SMAN 15 Semarang sebagai garda terdepan dalam mencerdaskan anak bangsa, perlu selalu menjaga kondisi kebugaran dan kesehatan tubuh secara mandiri, salah satunya dengan mengkonsumsi produk fermentasi non susu; maka perlu dilakukan pengenalan dan pelatihan pembuatan minuman probiotik yang murah dan mudah dibuat. Para guru dan administrasi di SMAN 15 Semarang adalah sasaran yang tepat untuk diberi penyuluhan, keterampilan dan pelatihan tentang pengolahan produk minuman fermentasi non susu (kombucha dan tepache). Untuk mendapatkan data mengenai peningkatan pengetahuan/pemahaman tentang produk teh kombucha dan tepache serta istilah bahasa inggrisnya, diberikan test sebelum dan sesudah pelaksanaan kegiatan. Berdasarkan hasil analisis data test didapatkan bahwa program ini secara statistik belum optimal dalam meningkatkan pengetahuan peserta mengenai minuman probiotik dan pembuatan teh kombucha dan tepache serta istilah bahasa inggrisnya.
\end{abstract}

Kata Kunci: kombucha, tepache, pelatihan

\section{Pendahuluan}

Pangan fungsional merupakan pangan alami yang mempunyai fungsi tidak hanya untuk memenuhi kebutuhan zat gizi, tetapi juga mempunyai fungsi fisiologis tertentu yang bermanfaat bagi kesehatan tubuh. Produk pangan fungsional adalah pangan yang dikonsumsi sebagai diet biasa, namun memiliki efek fisiologis dan dapat menjaga kesehatan tubuh. Produk pangan fungsional yang banyak dikonsumsi adalah minuman probiotik. Minuman probiotik adalah minuman yang mengandung sejumlah bakteri 
probiotik. Minuman probiotik yang telah dikenal secara luas selama ini diproduksi dengan menggunakan susu sapi sehingga relatif mahal harganya.

Salah satu jenis minuman probiotik adalah Kombucha, merupakan minuman kesehatan yang sangat menyegarkan yang dibuat dengan memfermentasi air teh dengan SCOBY (Symbiotic Consortium of Bacteria and Yeast) terutama spesies bakteri yang bersifat asam. Minuman probiotik ini memiliki berbagai keuntungan diantaranya sebagai penurunan kadar kolesterol dan tekanan darah, pengurangan penyebaran kanker, perbaikan hati, sistem kekebalan tubuh, dan fungsi gastrointestinal (Bhattacharya dkk., 2013; Chakravorty dkk., 2016; Leala dkk., 2018). Efek terapi minuman ini diduga berasal dari komposisi kimiawi minuman ini, terutama polifenol dan metabolit sekunder yang dihasilkan selama fermentasi (Watawana dkk., 2015). Saat ini banyak pula dikembangkan pembuatan minuman probiotik yang berasal dari sari buah (Perricone dkk., 2015). Penggunaan bahan baku alternatif seperti air teh, buah nanas dapat menghasilkan produk minuman probiotik yang lebih terjangkau namun memiliki kualitas yang baik.

Pada masa pandemi Covid-19 saat ini, selain dituntut untuk mematuhi dan melaksanakan protokol kesehatan, seperti menjaga kebersihan, menjaga jarak saat bersosialisasi, memakai masker, juga dituntut untuk selalu menjaga kondisi kebugaran dan kesehatan tubuh dengan cara mengkonsumsi makanan yang bergizi, serta mengkonsumsi produk pangan yang dapat memelihara dan meningkatkan imunitas tubuh. Para staf pendidik/guru dan administrasi di SMAN 15 Semarang dalam kegiatan mengajar membutuhkan kondisi tubuh dan kesehatan yang prima, agar tugas mencerdaskan anak bangsa tidak terkendala di masa pandemi Covid-19. Sehingga informasi dan pengetahuan tentang menjaga kondisi kebugaran dan kesehatan tubuh secara mandiri dengan cara membuat dan mengkonsumsi minuman fungsional probiotik, berupa produk fermentasi non susu sangatlah penting. Penyuluhan dan pelatihan pembuatan teh fermentasi kombucha dan tepache yang dapat digunakan sebagai alternatif minuman probiotik untuk meningkatkan imun tubuh, menurunkan kadar kolestrol dan hipertensi diharapkan dapat meningkatkan pola hidup sehat para guru dan masyarakat umum dilingkungan mereka.

Para guru dan staf administrasi di SMAN 15 Semarang adalah sasaran yang tepat untuk diberi penyuluhan, keterampilan dan pelatihan tentang pengolahan bahan pangan non susu menjadi produk minuman fermentasi sebagai minuman probiotik, berupa teh kombucha yang dibuat dari air teh manis dan tepache yang dibuat dari kulit dan daging buah nanas. Kegiatan pengenalan dan pelatihan/praktek ini bertujuan untuk memberikan pengetahuan dan keterampilan tentang cara pengolahan air teh, kulit dan daging nanas menjadi produk minuman probiotik secara fermentasi (kombucha dan tepache) yang inovatif.

\section{Metode Pelaksanaan}

Kegiatan pengabdian kepada masyarakat bagi guru dan staf administrasi SMAN 15 Semarang yang berlokasi di Jl. Kedungmundu No.34, Kelurahan Sambiroto, Kecamatan Tembalang, Kota Semarang, Jawa Tengah dilaksanakan pada bulan Desember 2020, berupa penyuluhan, pelatihan dan diskusi tentang pembuatan teh kombucha dan 
tepache, serta pengenalan istilah-istilah umum dalam Bahasa Inggris pada pembuatan teh kombucha. Saat pelaksanaan kegiatan juga dibagikan leaflet berisi materi yang diberikan oleh masing-masing penyaji. Evaluasi kegiatan berupa memberikan pretest dan posttest tentang materi teh fermentasi kombucha dan tepache, serta presensi peserta yang hadir pada kegiatan tersebut, untuk menjajaki dan mengukur pengetahuan dasar peserta serta mengetahui peningkatan pengetahuan/pemahaman tentang produk teh kombucha dan tepache serta istilah bahasa inggrisnya. Materi tes dibuat oleh tim pengabdian berdasarkan kerangka pelaksanaan program pengabdian, berupa kuesioner berisi pertanyaan perihal materi pelatihan, berbentuk pilihan ganda.

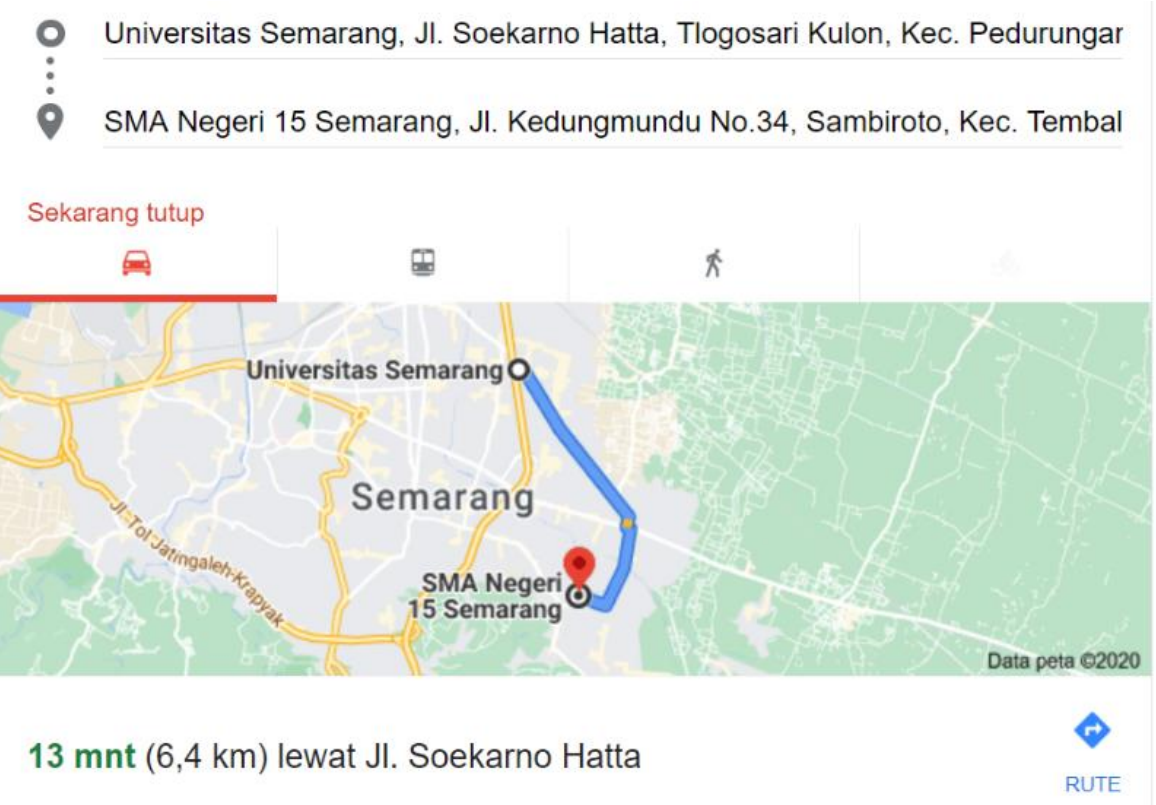

Gambar 1. Peta Lokasi SMAN 15 Semarang

\section{Hasil dan Pembahasan}

Peserta kegiatan pengabdian terdiri atas guru dan staf administrasi sejumlah 15 orang. Kegiatan pretest dan posttest dilakukan dengan cara pengisian kuisioner oleh perwakilan peserta yang dipilih secara acak, sebanyak 6 orang. Peserta test memiliki 2 kali kesempatan untuk mengerjakan test, yaitu sebelum serta sesudah pengenalan dan pelatihan, dimana terdiri atas 10 pertanyaan pilihan ganda.

Berdasarkan hasil uji statistik deskriptif data pretest dan posttest pada Tabel 1 diketahui bahwa rerata nilai pengetahuan tentang produk teh kombucha dan tepache serta istilah bahasa inggrisnya yang dikuasai oleh para peserta pengabdian sebelum diberikan program pengabdian adalah sebesar 5,60 dan menjadi 7,00 setelah mendapatkan program pengabdian.

Pada Tabel 1 terlihat bahwa variasi nilai pengetahuan peserta tentang minuman probiotik, pembuatan teh kombucha dan tepache serta istilah bahasa inggrisnya sebelum diberi program pengabdian adalah sebesar 7,30 lebih besar daripada pada variasi nilai sesudah diberikan program pengabdian yaitu sebesar 1,50. Hal ini menunjukkan bahwa perbedaan pengetahuan antar setiap peserta pengabdian menjadi lebih sempit (turun), yang berarti terjadi penyamaan rerata informasi/pengetahuan yang 
Vol. 2, No. 2, Mei 2021

ISSN 2721-4834

diperoleh dari program pengabdian. Hasil uji lanjut menggunakan uji-t didapatkan hasil seperti pada Tabel 2.

Tabel 1. Hasil Uji Deskriptif DataTest

\begin{tabular}{lllll}
\hline \hline Test & $N$ & Rerata Skor & Standar Deviasi & Varians \\
\hline \hline Awal (Pre Test) & 6 & 5,60 & 2,701 & 7,30 \\
Akhir (Post Test) & 6 & 7,00 & 1,224 & 1,50 \\
\hline
\end{tabular}

12

Tabel 2. Hasil Uji-t DataTest

\begin{tabular}{ccccc}
\hline \hline Test & N & Rerata Skor & Selisih Pre-Post & Sig.t \\
\hline Awal (Pre Test) & 6 & 5,60 & -1.40 & 0,16 \\
Akhir (Post Test) & 6 & 7,00 & & \\
\hline probabilitas & & & 0,05 \\
\hline \hline
\end{tabular}

Berdasarkan hasil uji-t diketahui bahwa terjadinya peningkatan pengetahuan peserta tentang minuman probiotik, pembuatan teh kombucha dan tepache serta istilah bahasa inggrisnya dengan selisih nilai rerata antara sebelum dan sesudah diberi program pengabdian sebesar 1.40, adalah besaran peningkatan yang terjadi akibat dari kegiatan pengabdian kepada masyarakat. Hasil uji-t pembandingan skor sebelum dan sesudah program pengabdian didapatkan nilai signifikansi sebesar 0,16 dimana nilai $p>0,05$. Berdasarkan hasil uji didapatkan bahwa program ini secara statistik belum optimal dalam meningkatkan pengetahuan peserta mengenai materi kegiatan.

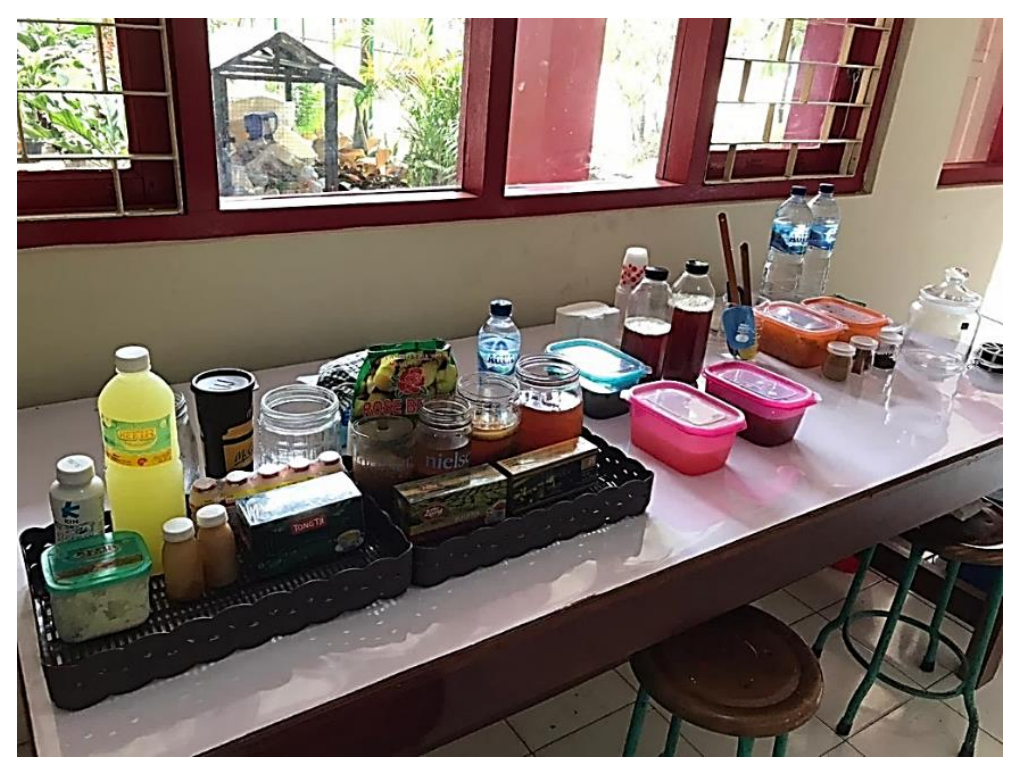

Gambar 2. Peralatan dan Bahan Pembuatan Minuman Probiotik 


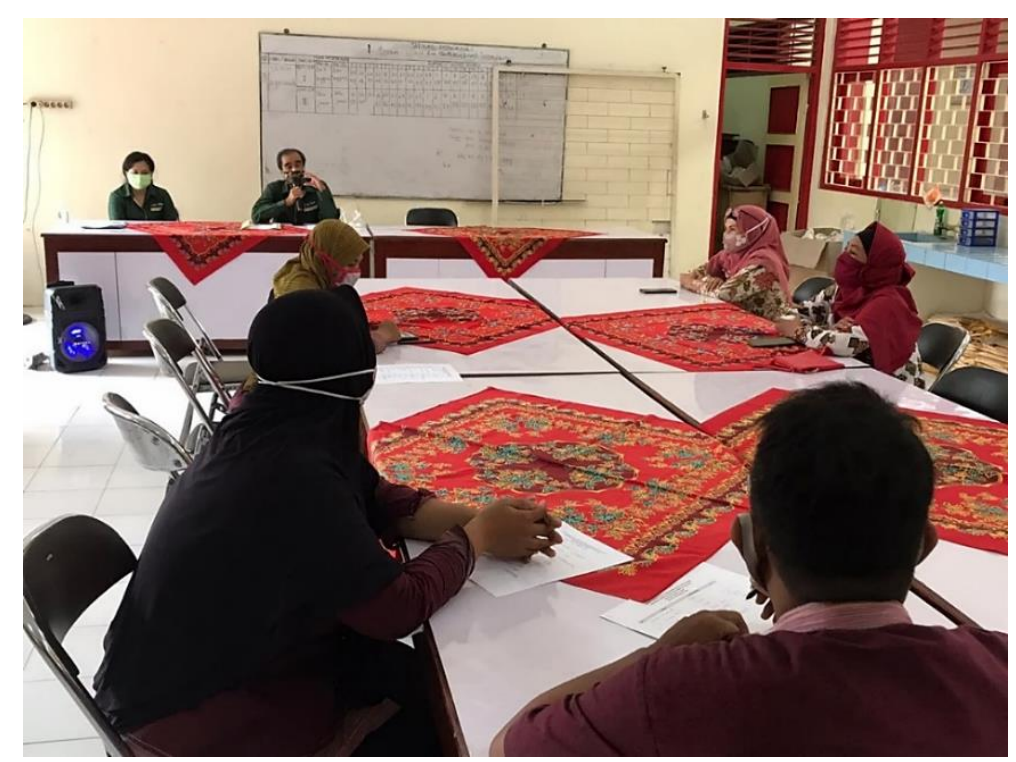

Gambar 3. Pelaksanaan Kegiatan Pengabdian Di SMAN 15 Semarang

\section{Kesimpulan}

Para guru dan staf administrasi di SMAN 15 Semarang sebagai peserta kegiatan telah mendapatkan penyuluhan dan pelatihan pembuatan minuman probiotik teh kombucha dan pembuatan tepache serta pengenalan istilah-istilah bahasa inggris tentang tehe kombucha. Peserta kegiatan telah memahami manfaat minuman probiotik sebagai minuman kesehatan yang dapat meningkatkan imunitas tubuh. Pengetahuan dan ketrampilan peserta kegiatan dalam pembuatan minuman probiotik non susu secara fermentasinya telah meningkat. Diharapkan pengetahuan dan ketrampilan dalam pembuatan minuman probiotik teh kombucha dan tepache dapat ditularkan kepada para siswa didik dan dapat dikembangkan serta dikomersialkan, sehingga dapat melengkapi produk branding sekolah SMAN 15 hasil Pembelajaran Kewirausahaan (PKWU) dalam rangka kegiatan praktek kewirausahaan siswa.

\section{Ucapan Terimakasih}

Ucapan terima kasih disampaikan kepada SMAN 15 Semarang yang telah menyediakan tempat dan waktu bagi berlangsungnya kegiatan Pengabdian kepada Masyarakat, serta Universitas Semarang yang telah mendukung dana untuk kegiatan ini.

\section{Referensi}

Bhattacharya, S., Gachhui, R., \& Sil, P.C. (2013). Effect Of Kombucha, A Fermented Black Tea In Attenuating Oxidative Stress Mediated Tissue Damage In Alloxan-Induced Diabetic Rats. Food and Chemical Toxicology, 60, 328-340. 
Chakravorty, S., Bhattacharya, S., Chatzinotas, A., Chakraborty, W., Bhattacharya, D., \& Gachhui, R. (2016). Kombucha Tea Fermentation: Microbial And Biochemical Dynamics. International Journal of Food Microbiology, 220, 63-72.

Leala, J. M., Suáreza, L. V., Jayabalanb, R., Orosa, J. H., Escalante-Aburtoa, A. (2018). A Review On Health Benefits Of Kombucha Nutritional Compounds And Metabolites. CYTA-Journal Of Food, 16(1), 390-399. https://doi.org/10.1080/19476337.2017.1410499

Perricone, M., Bevilacqua, A., Altieri, C., Sinigaglia, M., Corbo,M.R. (2015). Challenges for the production of probiotic fruit juices. Beverages, 1, 95-103. https://doi.org/10.339o/beverages1020095.

Watawana, M. I., Jayawardena, N., Gunawardhana, C. B., Waisundara, V. Y. (2015). Review Article Health, Wellness, and Safety Aspects of the Consumption of Kombucha. Journal of Chemistry, https://doi.org/10.1155/2015/591869 